\title{
Cord blood lymphocyte responses to food antigens for the prediction of allergic disorders
}

Naomi Kondo, Yuki Kobayashi, Shinji Shinoda, Kimiko Kasahara, Tsukako Kameyama, Shinichi Iwasa, Tadao Orii

\begin{abstract}
Proliferative responses of cord blood lymphocytes (CBLs) to food antigens and cord blood IgE concentrations were measured in 37 full term newborn infants for the prediction of allergic disorders. In these 37 infants who were followed up for two years, allergic history of the family was found in four (sensitivity $\mathbf{5 7 \cdot 1 \% )}$ and cord blood IgE concentrations were greater than $0.5 \mathrm{IU} / \mathrm{ml}$ in three (sensitivity $42.9 \%$ ) of seven infants who developed allergic disorders. When CBLs were stimulated twice by ovalbumin or bovine serum albumin, the value of the stimulation index in proliferative responses of CBLs to ovalbumin or bovine serum albumin was greater than 1.5 in six (sensitivity $85.7 \%$ ) of seven infants who developed allergic disorders. The specificity of the responses of CBLs in the prediction of the development of allergic disorders was 93.3\%. The proliferative responses of CBLs to food antigens were useful in the prediction of not only development of allergic disorders but also offending allergens. These observations provide further evidence that sensitisation is occurring in utero. This would appear to be increasingly important in the genesis of early atopic problems. As our follow up is only two years, in utero sensitisation is a prediction for the early development of atopic disease but only longer follow up will show whether this holds good for allergic disorders at any age.
\end{abstract}

(Arch Dis Child 1992;67:1003-1007)

Allergy often begins early in life, ${ }^{12}$ in many cases during the first year. Patients who suffer from allergic diseases are very difficult to cure completely. Prevention of allergic disorders in infants has been attempted by means of food and aeroallergen avoidance. ${ }^{3}$ The detection of a newborn at high risk of allergy is therefore important. Michel et $a l^{4}{ }^{4}$ and Magnusson ${ }^{5}$ reported that the $\operatorname{IgE}$ concentrations of cord blood appeared to be a good predictor of the development of allergy during infancy. However, it is not sufficient to predict 'high allergic risk newborns' on the basis of increased IgE concentrations of cord blood alone, because a raised cord blood IgE concentration is specific but not sensitive in the prediction of the development of allergic disorders. ${ }^{5-7}$ Moreover, Ruiz et al report that maternal blood may have contaminated cord blood in $7 \%$ of their cases. ${ }^{8}$ Allergic disorders that begin early in life are often atopic dermatitis and food allergy such as hens' egg and cows' milk sensitivities. We previously reported that the combination of the radioallergosorbent test and the detection of proliferative responses of peripheral blood lymphocytes to each food allergen is very useful in the diagnosis of hypersensitivity in children with atopic dermatitis who are sensitive to each food. ${ }^{9}$ In this study, cord blood IgE concentrations and proliferative responses of cord blood lymphocytes (CBLs) to each food antigen were measured for the prediction of the development of allergy during infancy.

\section{Subjects and methods}

SUBJECTS

Thirty seven full term newborn infants were investigated. Cord blood was collected immediately after birth by direct needle aspiration of the umbilical vein.

\section{CORD BLOOD IgE CONCENTRATIONS}

Cord blood IgE concentrations were measured by the enzyme linked immunoassay as previously described by Pene et al using a rabbit anti-IgE immunoglobulin (Dako), a murine antihuman IgE monoclonal antibody (Medical Biological Laboratory), and a goat antimouse immunoglobulin coupled to alkaline phosphatase (Sigma). ${ }^{10} \mathrm{~A}$ standard IgE serum (Behring) was used as a reference. The limit of the sensitivity of the assay was $0 \cdot 1 \mathrm{IU} / \mathrm{ml}$.

CELL PREPARATION AND CULTURE

CBLs were isolated from heparinised cord blood by gradient centrifugation in FicollPaque (Pharmacia). CBLs were suspended to give a density of $10^{6} / \mathrm{ml}$ in the culture medium consisting of Roswell Park Memorial Institute 1640 medium supplemented with $15 \%$ pooled human $\mathrm{AB}^{+}$serum, L-glutamine $(2 \mathrm{mM})$, penicillin $(100 \mathrm{units} / \mathrm{ml})$, and streptomycin $(100 \mu \mathrm{g} /$ $\mathrm{ml})$. In the case where CBLs were stimulated once by each food antigen, CBLs $\left(2 \times 10^{5}\right)$ were cultured at $0.2 \mathrm{ml}$ per well in round bottomed microtest plates (A/S Nunc) with or without various concentrations of food antigens $(0.25$, $2.5,25 \mu \mathrm{g} / \mathrm{ml}$, respectively) at $37^{\circ} \mathrm{C}$ for four days in a humidified atmosphere containing $5 \%$ carbon dioxide. ${ }^{9}$ In the case where CBLs were stimulated twice by each food antigen, CBLs $\left(10^{6} / \mathrm{ml}\right)$ were preincubated at $2 \mathrm{ml}$ per tube in the culture test tube with or without each food antigen $(2.5 \mu \mathrm{g} / \mathrm{ml})$ at $37^{\circ} \mathrm{C}$ for various numbers of days in a humidified atmosphere containing $5 \%$ carbon dioxide. Thereafter, cells were washed three times with phosphate buffered 
saline and resuspended to give a density of $10 \% \mathrm{ml}$ in the culture medium. Subsequently, the CBLs $\left(2 \times 10^{5}\right)$ were cultured at $0.2 \mathrm{ml}$ per well in round bottomed microtest plates with or without various concentrations of the same food antigen $(0 \cdot 25,2 \cdot 5,25 \mu \mathrm{g} / \mathrm{ml}$, respectively) at $37^{\circ} \mathrm{C}$ for various numbers of days in a humidified atmosphere containing $5 \%$ carbon dioxide.

\section{PROLIFERATIVE RESPONSES}

DNA synthesis was measured by adding $0.5 \mu \mathrm{Ci}$ $\left[{ }^{3} \mathrm{H}\right]$ thymidine (specific activity: $43 \mathrm{Ci} / \mathrm{mmol}$, Amersham) per well four hours before harvesting onto glass fibre filters. ${ }^{3} \mathrm{H}$ incorporation was measured by liquid scintillation counting, and the results were expressed as the mean of a triplicate. To compare responses between individuals, we also expressed the results as a stimulation index (SI; cpm, counts/minute).

$\mathrm{SI}=\frac{\text { Mean cpm in cultures stimulated with food antigens }}{\text { Mean cpm in unstimulated cultures }}$

\section{ANTIGENS}

Ovalbumin and bovine serum albumin were purchased from Wako Junyaku (Japan). The purity of ovalbumin or bovine serum albumin used was confirmed by sodium dodecylsulfate polyacrylamide gel electrophoresis as a single band, $45 \mathrm{~K}$ or $66 \mathrm{~K}$, respectively.

\section{CONDUCT OF THE STUDY}

Cord blood IgE concentrations and proliferative responses of CBLs to each food antigen were measured at birth. The allergic history of the family (parents and siblings) was also investigated at that time.

All 37 newborn infants were followed up for two years. Allergic disorders or symptoms (atopic dermatitis, bronchial asthma, allergic rhinitis, food allergy, wheezy bronchitis) which developed in the infants were investigated. Clinical criteria that defined allergy were chosen
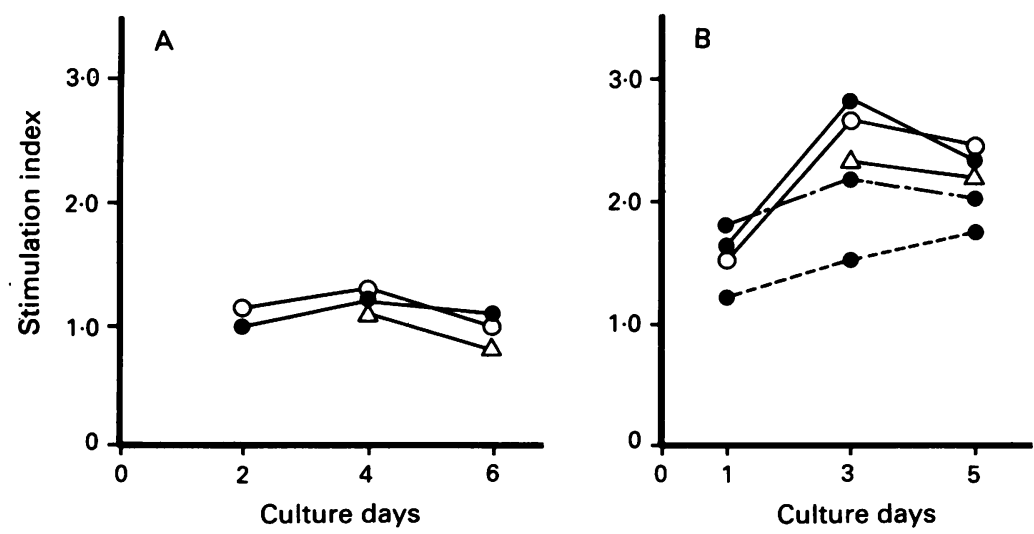

A time response study of proliferative responses of $C B L$ s stimulated by ovalbumin. $(A)$ Proliferative responses of $C B L$ s stimulated once by ovalbumin. The $X$ axis shows culture periods; $\bigcirc \mathrm{O}: 25 \mathrm{\mu g} / \mathrm{ml}$ of ovalbumin, $2.5 \mathrm{\mu g} / \mathrm{ml}$ of ovalbumin, $\triangle \triangle \triangle: 0.25 \mu \mathrm{g} / \mathrm{ml}$ of ovalbumin. $(B)$ Proliferative responses of $C B L s$ stimulated $\triangle \longrightarrow \triangle: 0 \cdot 25 \mu \mathrm{g} / \mathrm{ml}$ of ovalbumin. (B) Proliferative responses of $C B L \mathrm{~s}$ stimula twice by ovalbumin. The $X$ axis shows culture periods after three, five, or seven day
preincubation with a concentration of $2.5 \mu \mathrm{g} / \mathrm{ml}$ of ovalbumin; -1 cultures with $2.5 \mu \mathrm{g} / \mathrm{ml}$ of ovalbumin after three day preincubation, $\mathrm{O}-\mathrm{O}$ : cultures with $25 \mu \mathrm{g} / \mathrm{ml}$ of ovalbumin after five day preincubation, : cultures with $2.5 \mu \mathrm{g} / \mathrm{ml}$ of ovalbumin after five day preincubation, $\triangle \longrightarrow \triangle$ : cultures with $0 \cdot 25 \mu \mathrm{g} / \mathrm{ml}$ of ovalbumin after five day preincubation, - . - . : cultures with $2 \cdot 5 \mu \mathrm{g} / \mathrm{ml}$ of ovalbumin after seven day preincubation. according to those of Orgel et al, ${ }^{\prime}$ and Kjellman. ${ }^{11}$ Diagnosis of atopic dermatitis was defined by the criteria of Hanifin. ${ }^{12}$ The severity of atopic dermatitis was graded by the food challenge symptom scores for skin of Bock et $a l .{ }^{13}$ Diagnosis of food allergy was defined on the basis of clinical history and double blind placebo controlled food challenges. ${ }^{13}$ Consequently, the relationships among allergic history of the family (parents and siblings), cord blood IgE concentrations, proliferative responses of CBLs to each food antigen, and the development of allergic disorders in the infant for two years were investigated.

\section{STATISTICAL ANALYSIS}

Frequencies were compared by Fisher's exact test $(2 \times 2$ contingency tables).

\section{Results}

\section{PROLIFERATIVE RESPONSES OF CBLS TO EACH} FOOD ANTIGEN

CBLs stimulated twice by ovalbumin or bovine serum albumin exhibited proliferative responses in some subjects. As the peak proliferation was seen under the culture conditions of five day preincubation and a subsequent three day culture with a concentration of $2 \cdot 5$ or $25 \mu \mathrm{g} / \mathrm{ml}$ of each antigen (figure), cultures were routinely harvested on these culture days. The maximal proliferative responses of CBLs stimulated once and twice by ovalbumin or bovine serum albumin for the whole series of all 37 subjects are shown in table 1 , in the order of the values of the SI in responses to ovalbumin or bovine serum albumin. Although CBLs stimulated once by ovalbumin or bovine serum albumin showed no proliferative responses in any subject, CBLs stimulated twice exhibited proliferative responses in some subjects. For convenience, subjects were divided into two groups according to the values of the SI: greater than 1.5 and less than 1.5 . SI values greater than 1.5 in either ovalbumin stimulation or bovine serum albumin stimulation were seen in eight $(21 \cdot 6 \%$, subjects $1-8)$ of 37 subjects, as shown in table 1 .

\section{CORD BLOOD IgE CONCENTRATIONS AND}

ALLERGIC HISTORY OF THE FAMILY

Table 1 also shows cord blood IgE concentrations and the allergic history of the family for each subject. According to the report previously described by Michel et al, ${ }^{4}$ subjects were divided into two groups according to the cord blood $\mathrm{IgE}$ concentrations: greater than $0.5 \mathrm{IU} / \mathrm{ml}$ and less than $0.5 \mathrm{IU} / \mathrm{ml}$. Cord blood IgE concentrations were greater than $0.5 \mathrm{IU} / \mathrm{ml}$ in $10(27.0 \%)$ of 37 subjects. There was allergic history of the family (parents and siblings) in $11(29.7 \%)$ of 37 subjects.

\section{RELATIONSHIP BETWEEN VARIABLES FOR} PREDICTION

There was allergic history of the family (parents and siblings) in four $(40.0 \%)$ of 10 subjects whose cord blood IgE concentrations were 
Table 1 Cord blood IgE concentrations, proliferative responses of CBLs stimulated once or twice by ovalbumin or bovine serum albumin, allergic history of the family, and allergic disorders developed in infants who were followed up for two years

\begin{tabular}{|c|c|c|c|c|c|c|c|}
\hline \multirow[t]{3}{*}{ Subjects } & \multirow{3}{*}{$\begin{array}{l}\text { Allergic } \\
\text { history } \\
\text { of the } \\
\text { family }\end{array}$} & \multirow{3}{*}{$\begin{array}{l}\text { Cord } \\
\text { blood } \\
I g E \\
(I U / m l)\end{array}$} & \multicolumn{4}{|c|}{$\begin{array}{l}\text { Proliferative responses }\left(S I^{*}\right) \text { of } \\
C B L s \text { stimulated }\end{array}$} & \multirow{3}{*}{$\begin{array}{l}\text { Allergic disorders } \\
\text { developed in infants } \\
A D \text { (severity, offending } \\
\text { foods, onset) and } \\
W H \text { (onset) }\end{array}$} \\
\hline & & & \multicolumn{2}{|l|}{ Once } & \multicolumn{2}{|l|}{ Twice } & \\
\hline & & & Ovalbumin & $\begin{array}{l}\text { Bovine serum } \\
\text { albumin }\end{array}$ & Ovalbumin & $\begin{array}{l}\text { Bovine serum } \\
\text { albumin }\end{array}$ & \\
\hline $\begin{array}{l}1 \\
2\end{array}$ & $\mathrm{~B}(\mathrm{AD})$ & $\begin{array}{l}1 \cdot 1 \dagger \\
0 \cdot 2\end{array}$ & $\begin{array}{l}0.59 \\
1.23\end{array}$ & $\begin{array}{l}1 \cdot 24 \\
1 \cdot 51\end{array}$ & $\begin{array}{l}1 \cdot 04 \\
2 \cdot 81 \dagger\end{array}$ & $\begin{array}{l}3 \cdot 29+ \\
1 \cdot 17\end{array}$ & $\begin{array}{l}\text { AD (severe, cows' milk, } 4 \text { months) } \\
\text { AD (moderate, hens' egg and } \\
\text { soybean, } 11 \text { months) }\end{array}$ \\
\hline 3 & & $<0.1$ & $1 \cdot 79$ & 0.54 & $2 \cdot 45 t$ & $2 \cdot 15 t$ & $\begin{array}{l}\mathrm{AD} \text { (mild, hens' egg, } 8 \text { months }) \\
\text { WH }(1 \cdot 3 \text { years })\end{array}$ \\
\hline $\begin{array}{l}4 \\
5\end{array}$ & $\mathbf{M}(\mathbf{B A})$ & $\begin{array}{l}2 \cdot 3 \dagger \\
0 \cdot 2\end{array}$ & $\begin{array}{l}1.03 \\
0.94\end{array}$ & $\begin{array}{l}1 \cdot 03 \\
0 \cdot 71\end{array}$ & $\begin{array}{l}1 \cdot 28 \\
1 \cdot 07\end{array}$ & $\begin{array}{l}2 \cdot 25 t \\
2 \cdot 07 \dagger\end{array}$ & $\begin{array}{l}\text { AD (moderaie, cows' milk, } \\
4 \text { months) }\end{array}$ \\
\hline 6 & $\mathbf{F}(\mathbf{A R})$ & $<0 \cdot 1$ & $0 \cdot 78$ & 0.95 & $1.82 t$ & $2 \cdot 00 \dagger$ & $\begin{array}{l}\mathrm{AD} \text { (moderate, hens' egg, } 1 \text { year), } \\
\text { WH (1 year) }\end{array}$ \\
\hline $\begin{array}{l}7 \\
8\end{array}$ & & $\begin{array}{l}2 \cdot 7 \dagger \\
0.7 \dagger\end{array}$ & $\begin{array}{l}0.80 \\
0.97\end{array}$ & $\begin{array}{l}0.58 \\
1.25\end{array}$ & $\begin{array}{l}1.82 \dagger \\
1.10\end{array}$ & $\begin{array}{l}1.27 \\
1.79\end{array}$ & AD (severe, hens' egg, 11 months) \\
\hline 9 & $\mathrm{M}(\mathrm{AR}), \mathrm{B}(\mathrm{AD})$ & $0 \cdot 3$ & 0.72 & 0.69 & $1 \cdot 44$ & $1 \cdot 16$ & \\
\hline 10 & & $<0.1$ & 0.97 & $0 \cdot 77$ & 0.99 & $1 \cdot 34$ & \\
\hline $\begin{array}{l}11 \\
12\end{array}$ & $\mathbf{F}(\mathbf{A R})$ & $\begin{array}{r}0.8 \dagger \\
<0.1\end{array}$ & $\begin{array}{l}0.92 \\
0.66\end{array}$ & $\begin{array}{l}0 \cdot 84 \\
1 \cdot 01\end{array}$ & $\begin{array}{l}0.94 \\
1 \cdot 27\end{array}$ & $\begin{array}{l}1.31 \\
0.83\end{array}$ & \\
\hline 13 & & $\begin{array}{r}<0.1 \\
0.2\end{array}$ & $\begin{array}{l}0.66 \\
0.56\end{array}$ & $\begin{array}{l}1.01 \\
0.67\end{array}$ & 1.23 & $\begin{array}{l}0.83 \\
1 \cdot 17\end{array}$ & \\
\hline 14 & & $<0.1$ & $1 \cdot 10$ & 0.83 & $1 \cdot 23$ & 1.04 & \\
\hline 15 & & $<0 \cdot 1$ & 1.00 & $1 \cdot 02$ & $1 \cdot 14$ & $1 \cdot 16$ & \\
\hline 16 & & $<0 \cdot 1$ & 1.03 & 0.97 & 0.69 & $1 \cdot 16$ & \\
\hline 17 & $\mathbf{F}(\mathbf{A R})$ & $0 \cdot 3$ & $0 \cdot 73$ & $0 \cdot 84$ & 0.97 & $1 \cdot 14$ & \\
\hline 18 & & $<0 \cdot 1$ & $0 \cdot 77$ & $0 \cdot 70$ & 0.92 & $1 \cdot 11$ & \\
\hline 19 & & $<0 \cdot 1$ & $1 \cdot 26$ & 1.25 & 0.95 & 1.09 & \\
\hline 20 & & $0.5 \dagger$ & $0 \cdot 71$ & $1 \cdot 15$ & 0.69 & 1.01 & \\
\hline 21 & $\mathbf{M}(\mathrm{AD})$ & $<0 \cdot 1$ & 1.03 & 0.73 & 0.90 & 0.97 & \\
\hline 22 & & $1 \cdot 5 \dagger$ & 0.61 & 0.43 & 0.67 & 0.94 & \\
\hline 23 & & $2 \cdot 3 \dagger$ & 0.98 & 0.79 & 0.88 & 0.90 & \\
\hline 24 & M(AR) & $3.6 \dagger$ & 0.59 & 0.41 & $0 \cdot 83$ & 0.90 & \\
\hline 25 & $\mathrm{~S}(\mathrm{AD})$ & $2 \cdot 7 \dagger$ & $0 \cdot 84$ & $0 \cdot 87$ & $0 \cdot 89$ & 0.85 & AD (severe, soybean, 1.7 years) \\
\hline 26 & & $<0 \cdot 1$ & 0.91 & $1 \cdot 12$ & 0.63 & 0.89 & \\
\hline 27 & & $<0 \cdot 1$ & $1 \cdot 13$ & 0.97 & $0 \cdot 81$ & 0.68 & \\
\hline 28 & & $0 \cdot 2$ & 0.95 & 0.87 & 0.79 & 0.69 & \\
\hline 29 & $\mathrm{M}(\mathrm{AR}), \mathrm{B}(\mathrm{AD})$ & $<0 \cdot 1$ & 0.77 & $1 \cdot 17$ & 0.78 & 0.73 & \\
\hline 30 & & $<0.1$ & 0.61 & 0.64 & 0.72 & 0.77 & \\
\hline $\begin{array}{l}31 \\
32\end{array}$ & $\mathbf{F}(\mathbf{B A})$ & $\begin{array}{r}<0.1 \\
0.2\end{array}$ & $\begin{array}{l}0.93 \\
1.09\end{array}$ & $\begin{array}{l}0.79 \\
0.63\end{array}$ & $\begin{array}{l}0.67 \\
0.61\end{array}$ & $\begin{array}{l}0.66 \\
0.54\end{array}$ & \\
\hline 33 & & $0 \cdot 2$ & $1 \cdot 18$ & 0.96 & 0.43 & 0.51 & \\
\hline 34 & & $<0.1$ & 0.42 & 0.47 & 0.43 & 0.50 & \\
\hline 35 & & 0.2 & 0.93 & 0.71 & 0.39 & 0.50 & \\
\hline 36 & & $<0.1$ & 0.87 & 0.72 & 0.48 & $0 \cdot 38$ & \\
\hline 37 & & 0.2 & 0.90 & 0.81 & 0.46 & 0.45 & \\
\hline
\end{tabular}

B, brother; S, sister; F, father; M, mother; AD, atopic dermatitis; AR, allergic rhinitis; BA, bronchial asthma; WH, wheezy bronchitis. "Mean of triplicate.

$\dagger \geqslant 0.5 \mathrm{IU} / \mathrm{ml}$ for cord blood IgE concentration or $\geqslant 1.5$ for SI of proliferative responses of CBLs.

greater than $0.5 \mathrm{IU} / \mathrm{ml}$ and in three $(37.5 \%)$ of eight subjects whose SI was greater than 1.5 in proliferative responses of CBLs stimulated twice by ovalbumin or bovine serum albumin (table 2A). In four $(50.0 \%)$ of eight subjects whose SI was greater than 1.5 in proliferative

Table 2 Relationship between allergic history of the family, cord blood IgE concentrations, and proliferative responses of CBLs stimulated twice by ovalbumin or bovine serum albumin

\begin{tabular}{|c|c|c|c|c|}
\hline \multirow[t]{2}{*}{$\begin{array}{l}\text { (A) Allergic history } \\
\text { of the family }\end{array}$} & \multicolumn{2}{|c|}{$\begin{array}{l}\text { Cord blood IgG } \\
\text { concentrations } \\
(I U / m l)\end{array}$} & \multicolumn{2}{|c|}{$\begin{array}{l}\text { Proliferative } \\
\text { responses of CBLs } \\
\text { to ovalbumin or } \\
\text { bovine serum } \\
\text { albumin }(S I)\end{array}$} \\
\hline & $<0.5$ & $\geqslant 0.5$ & $<1 \cdot 5$ & $\geqslant 1.5$ \\
\hline $\begin{array}{l}\text { Negative (26): } \\
\text { Positive (11) }\end{array}$ & $\begin{array}{r}20 \\
7\end{array}$ & $\begin{array}{l}6 \\
4\end{array}$ & $\begin{array}{r}21 \\
8\end{array}$ & $\begin{array}{l}5 \\
3\end{array}$ \\
\hline Total & 27 & 10 & 29 & 8 \\
\hline \multirow[t]{2}{*}{$\begin{array}{l}\text { (B) Cord blood IgE } \\
\text { concentrations } \\
(I U / m l)\end{array}$} & & \multicolumn{3}{|c|}{$\begin{array}{l}\text { Proliferative responses of } C B L s \\
\text { to ovalbumin or bovine serum } \\
\text { albumin }(S I)\end{array}$} \\
\hline & & \multicolumn{2}{|l|}{$<1.5$} & $\geqslant 1.5$ \\
\hline $\begin{array}{l}<0.5(27) \dagger \\
\geqslant 0.5(10) \dagger\end{array}$ & & \multicolumn{2}{|l|}{$\begin{array}{r}23 \\
6\end{array}$} & $\begin{array}{l}4 \\
4\end{array}$ \\
\hline Total & & \multicolumn{2}{|l|}{29} & 8 \\
\hline
\end{tabular}

responses of CBLs stimulated twice by ovalbumin or bovine serum albumin cord blood $\operatorname{IgE}$ concentrations were greater than $0.5 \mathrm{IU} / \mathrm{ml}$ (table 2B).

\section{ALLERGIC DISORDERS AND SYMPTOMS IN} INFANTS

All 37 newborns were followed up for two years. As shown in table 1, atopic dermatitis or atopic dermatitis and wheezy bronchitis developed in seven $(18.9 \%)$ of 37 subjects. Allergic manifestations in these seven infants are shown in table 1 .

\section{RELATIONSHIP BETWEEN VARIABLES FOR} PREDICTION AND ALLERGIC DISORDERS IN INFANTS

This is summarised in table 3 . The sensitivity and specificity of each variable in the prediction of the development of allergic disorders are also shown in table 3 . There was a history of allergy in the family in four (sensitivity $57 \cdot 1 \%$ ) of seven infants who developed allergic disorders. Cord blood IgE concentrations were greater than 0.5 $\mathrm{IU} / \mathrm{ml}$ in three (sensitivity $42 \cdot 9 \%$ ) of seven infants who developed allergic disorders. SI was greater than 1.5 in proliferative responses of CBLs stimulated twice by ovalbumin or bovine serum albumin in six of seven infants who developed allergic disorders (sensitivity $85 \cdot 7 \%$, 
$\mathrm{p}<0.0005$ compared with non-allergic group) (table 3). In comparison, among the 30 infants of the non-allergic group, seven $(23 \cdot 3 \%)$ had positive allergic history of the family, seven (23.3\%) had cord blood IgE concentrations greater than $0.5 \mathrm{IU} / \mathrm{ml}$, and only two $(6.7 \%)$ had an SI greater than 1.5 in proliferative responses of CBLs stimulated twice by ovalbumin or bovine serum albumin. The specificities of positive allergic history of the family, cord blood IgE concentration greater than $0.5 \mathrm{IU} / \mathrm{ml}$, and an SI greater than 1.5 in proliferative responses of CBLs stimulated by ovalbumin or bovine serum albumin were $76 \cdot 7 \%, 76 \cdot 7 \%$, and $93.3 \%$, respectively. As shown in table 4 , in all seven infants who developed allergic disorders, cord blood IgE concentrations were greater than $0.5 \mathrm{IU} / \mathrm{ml}$ and/or the SI was greater than $1.5 \mathrm{in}$ proliferative responses of CBLs stimulated twice by ovalbumin or bovine serum albumin. The sensitivity and specificity of this combination for prediction were $100 \%(\mathrm{p}<0.0005$ compared with the non-allergic group) and $76 \cdot 7 \%$, respectively (table 4).

Moreover, as shown in table 1 , four infants (subjects 2, 3, 6, and 7) with atopic dermatitis who are sensitive to hens' egg had proliferative responses of CBLs, at least, to ovalbumin, and two infants (subjects 1 and 5) with atopic dermatitis who are sensitive to cows' milk had

Table 3 Relationship between allergic history of the family, cord blood IgE concentrations, proliferative responses of CBLs stimulated twice by ovalbumin or bovine serum albumin, and the numbers of infants who developed allergic disorders for two years

\begin{tabular}{|c|c|c|c|c|c|c|}
\hline & \multicolumn{2}{|c|}{$\begin{array}{l}\text { Allergic history } \\
\text { of the } \\
\text { family }\end{array}$} & \multicolumn{2}{|c|}{$\begin{array}{l}\text { Cord blood IgE } \\
\text { concentrations } \\
(I U / m l)\end{array}$} & \multicolumn{2}{|c|}{$\begin{array}{l}\text { Proliferative } \\
\text { responses of } C B L s \\
\text { to ovalbumin or } \\
\text { bovine serum } \\
\text { albumin }(S I)\end{array}$} \\
\hline & Negative & Positive & $<0 \cdot 5$ & $\geqslant 0.5$ & $<1 \cdot 5$ & $\geqslant 1 \cdot 5$ \\
\hline $\begin{array}{l}\text { Allergic disorders devel } \\
\text { Non-allergic }(30)^{*} \\
\text { Allergic }(7)^{*}\end{array}$ & $\begin{array}{l}\text { ed in infant } \\
23 \\
3\end{array}$ & $\begin{array}{l}7 \\
4\end{array}$ & $\begin{array}{r}23 \\
4\end{array}$ & $\begin{array}{l}7 \\
3\end{array}$ & $\begin{array}{r}28 \\
1\end{array}$ & $\begin{array}{l}2 \\
6 \ddagger\end{array}$ \\
\hline Total & 26 & 11 & 27 & 10 & 29 & 8 \\
\hline $\begin{array}{l}\text { Positive rate (\%) } \\
\text { Sensitivity (\%)† } \\
\text { Specificity }(\%) \dagger \\
\text { Accuracy }(\%) \dagger\end{array}$ & \multicolumn{2}{|c|}{$\begin{array}{l}29 \cdot 7(11 / 37) \\
57 \cdot 1(4 / 7) \\
76 \cdot 7(23 / 30) \\
73 \cdot 0(27 / 37)\end{array}$} & \multicolumn{2}{|c|}{$\begin{array}{l}27 \cdot 0(10 / 37) \\
42 \cdot 9(3 / 7) \\
76 \cdot 7(23 / 30) \\
70 \cdot 3(26 / 37)\end{array}$} & \multicolumn{2}{|c|}{$\begin{array}{l}21 \cdot 6(8 / 37) \\
85 \cdot 7(6 / 7) \ddagger \\
93 \cdot 3(28 / 30) \\
91 \cdot 9(34 / 37)\end{array}$} \\
\hline
\end{tabular}

*The numbers in parentheses are the numbers of infants who did not develop or developed allergic disorders for two years.

†Sensitivity: true positives/(true positives +false negatives); specificity: true negatives/(false positives + true negatives); and accuracy: (true negatives + true positives)/total number of cases. $\ddagger \mathrm{p}<\mathbf{0 . 0 0 0 5}$ compared with non-allergic group.

Table 4 Relationship between the numbers of infants who developed allergic disorders for two years and the combination of cord blood IgE concentrations and proliferative responses of $C B L$ stimulated twice by ovalbumin or bovine serum albumin

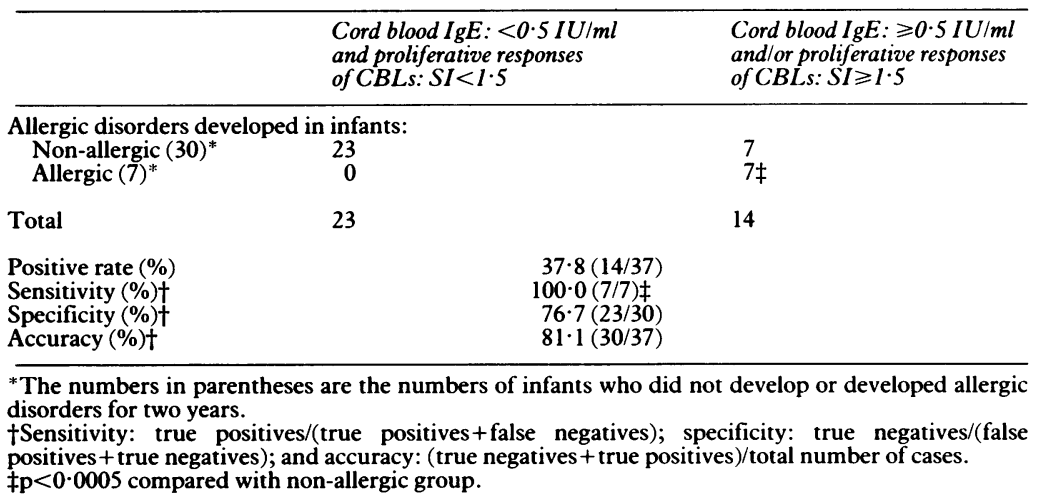

proliferative responses of CBLs to bovine serum albumin but not to ovalbumin. One patient (subject 25) with atopic dermatitis who is sensitive to soybean had no proliferative responses of CBLs to either ovalbumin or bovine serum albumin (table 1).

\section{Discussion}

Several investigators have shown that newborn infants with raised IgE concentrations of cord blood are at increased risk of developing allergic diseases. $^{4-6}$ Michel et $a l^{4}$ and Magnusson ${ }^{5}$ reported that the $\operatorname{IgE}$ concentrations of cord blood appeared to be more predictive for the development of allergy in infancy than the family history. Moreover, Iikura et al reported that the measurement of specific IgG and $\mathrm{IgG}_{4}$ in cord blood could be useful in the prediction of the development of allergic diseases and of offending foods. ${ }^{14}$ However, several reports showed that a raised cord blood IgE concentration is specific but not sensitive in the prediction of the development of allergic disorders. ${ }^{5-7}$ Kjellman and Croner reported that although the specificity was $97 \%$, the sensitivity was $28 \%,{ }^{7}$ and Magnusson reported that although the specificity was $93 \%$, the sensitivity was $68 \%$. $^{5}$ These data indicate that a low cord blood $\mathrm{IgE}$ concentration does not exclude the development of allergic diseases.

Allergic disorders that begin early in life are often atopic dermatitis and food allergy such as hens' egg and cows' milk sensitivities. We previously reported that in children with atopic dermatitis who are sensitive to certain foods, there is no significant correlation between the proliferative responses of peripheral blood lymphocytes and radioallergosorbent test to each food allergen, and that the proliferative responses of peripheral blood lympocytes to each food allergen is very useful in the diagnosis of hypersensitivity in food sensitive atopic dermatitis. ${ }^{9}$

In humans, sensitisation in utero was suggested by several investigators. ${ }^{415}$ In this study, proliferative responses of CBLs to food antigens were measured. Although CBLs stimulated once by ovalbumin or bovine serum albumin showed no proliferative responses in any subject, CBLs stimulated twice by ovalbumin or bovine serum albumin exhibited proliferative responses in some subjects. We utilised the optimum double stimulation times of five and three days with a concentration of 2.5 or $25 \mu \mathrm{g} / \mathrm{ml}$ of each antigen. Our observations provide further evidence that sensitisation is occurring in utero. This would appear to be increasingly important in the genesis of early atopic problems. It may be due to the weakness of in vivo sensitisation by offending allergens in the maternal uterus that CBLs responded to ovalbumin or bovine serum albumin only in double stimulations. The specificity $(93.3 \%)$ and the sensitivity $(85 \cdot 7 \%)$ of the proliferative responses of CBLs in the prediction of the development of allergic disorders were greater than those of the raised cord blood IgE concentrations or the allergic history of the family, respectively. Moreover, the sensitivity was 
increased by combining the cord blood IgE concentrations and proliferative responses of CBLs to food allergens. The measurement of proliferative responses of CBLs was also able to predict offending allergens. However, Ruiz et al report that maternal blood may have contaminated cord blood in $7 \%$ of their cases. ${ }^{8}$ In a further experiment, proliferative responses of CBLs to each food allergen will be compared with the responses of maternal peripheral blood lymphocytes and the responses of peripheral blood lymphocytes at seven days in the subjects whose CBLs responded to the allergen. Thus, the possibility of maternal blood contamination and the effects on the responses of CBLs will be investigated.

Taken together, our results indicate that the detection of the proliferative responses of CBLs to food antigens is useful in the prediction of not only the development of allergic disorders but also offending allergens. However, as our follow up is only two years, in utero sensitisation is a prediction for the early development of atopic disease but only longer follow up will show whether this holds good for allergic disorders at any age.

1 Orgel HA, Hamburger RN, Bazaral M, et al. Development of IgE and allergy in infancy. $\mathcal{F}$ Allergy Clin Immunol 1975;56: 296-307.

2 Pearlman DS, Bierman CW. Allergic disorders. In: Stiehm $\mathrm{ER}$, ed. Immunologic disorders in infants and children. 3rd Ed. Philadelphia: WB Saunders, 1989:439-74.
3 Hamburger RN, Heller S, Mellon MH, O'Connor RD, Seiger RS. Current status of the clinical and immunologic consequences of a prototype allergic disease prevention program. Ann Allergy 1983;51:281-90.

4 Michel FB, Bousquet J, Greillier $P$, Robinet-Levy $M$ Coulomb Y. Comparison of cord blood immunoglobulin E concentrations and maternal allergy for the prediction of concentrations and maternal allergy for the prediction of
atopic diseases in infancy. $\mathcal{J}$ Allergy Clin Immunol 1980;65: 422-30.

5 Magnusson GGM. Cord serum IgE in relation to family history and as predictor of atopic disease in early infancy. Allergy 1988;43:241-51.

6 Croner S, Kjellman NIM, Eriksson B, Roth A. IgE screening in 1701 newborn infants and the development of atopic disease during infancy. Arch Dis Child 1982;57:364-8.

7 Kjellman NIM, Croner S. Cord blood IgE determination for allergy prediction-a follow-up to seven years of age in 1651 children. Ann Allergy 1984;53:167-71.

8 Ruiz'RGG, Richards D, Kemeny DM, Price JF. Neonatal IgE: a poor screen for atopic disease. Clin Exp Allergy 1991 21:467-72.

9 Kondo N, Agata H, Fukutomi O, Motoyoshi F, Orii T. Lymphocyte responses to food antigens in patients with atopic dermatitis who are sensitive to foods. $f$ Allergy Clin Immunol 1990;86:253-60.

10 Pene J, Rousset F, Briere F, et al. IgE production by normal human lymphocytes is induced by interleukin 4 and suppressed by interferons $\gamma$ and $\alpha$ and prostaglandin $\mathrm{E}_{2}$. suppressed by interferons $\gamma$ and $\alpha$ and
Proc Nat Acad Sci USA 1988;85:6880-4.

11 Kiellman NIM. Predictive value of high IgE levels in jellman NIM. Predictive value of high IgE
children. Acta Paediatr Scand 1976;65:465-71.

12 Hanifin JM. Atopic dermatitis. F Allergy Clin Immunol 1984 73:211-22.

13 Bock SA, Sampson HA, Atkins FM, et al. Double-blind, placebo-controlled food challenge (DBPCFC) as an office procedure: a manual. $\mathcal{f}$ Allergy Clin Immunol 1988;82: 986-97.

14 Iikura Y, Akimoto K, Odajima Y, Akazawa A, Nagakura T How to prevent allergic disease I. Study of specific IgE, IgG and IgG4 antibodies in serum of pregnant mothers, cord blood and infants. Int Arch Allergy Appl Immunol 1989;88:250-2.

15 Kuroume T, Oguri M, Matsumura T, et al. Milk sensitivity and soybean sensitivity in the production of eczematous manifestations in breast-fed infants with particular reference to intra-uterine sensitization. Ann Allergy 1976; reference 